OPEN ACCESS

Edited by:

Tohru Yoshihisa,

University of Hyogo, Japan

Reviewed by:

Hyouta Himeno,

Hirosaki University, Japan

Naoyuki Kataoka,

Departments of Applied Animal

Sciences and Applied Biological

Chemistry, The University

of Tokyo, Japan

${ }^{*}$ Correspondence:

Kent E. Duncan

kent.duncan@zmnh.uni-hamburg.de

Toshinobu Fujiwara

tosinobu@phar.kindai.ac.jp

Specialty section:

This article was submitted to

RNA,

a section of the journal

Frontiers in Genetics

Received: 18 December 2018

Accepted: 28 March 2019

Published: 02 May 2019

Citation:

Otsuka H, Fukao A, Funakami Y, Duncan KE and Fujiwara T (2019) Emerging Evidence of Translational

Control by AU-Rich

Element-Binding Proteins.

Front. Genet. 10:332.

doi: 10.3389/fgene.2019.00332

\section{Emerging Evidence of Translational Control by AU-Rich Element-Binding Proteins}

\author{
Hiroshi Otsuka ${ }^{1}$, Akira Fukao ${ }^{2}$, Yoshinori Funakami ${ }^{2}$, Kent E. Duncan ${ }^{3 *}$ and \\ Toshinobu Fujiwara ${ }^{2 *}$
}

${ }^{1}$ Graduate School of Frontier Sciences, University of Tokyo, Kashiwa, Japan, ${ }^{2}$ Kindai University, Higashi-osaka, Japan, ${ }^{3}$ University Medical Center Hamburg-Eppendorf, Hamburg, Germany

RNA-binding proteins (RBPs) are key regulators of posttranscriptional gene expression and control many important biological processes including cell proliferation, development, and differentiation. RBPs bind specific motifs in their target mRNAs and regulate mRNA fate at many steps. The AU-rich element (ARE) is one of the major cis-regulatory elements in the $3^{\prime}$ untranslated region (UTR) of labile mRNAs. Many of these encode factors requiring very tight regulation, such as inflammatory cytokines and growth factors. Disruption in the control of these factors' expression can cause autoimmune diseases, developmental disorders, or cancers. Therefore, these mRNAs are strictly regulated by various RBPs, particularly ARE-binding proteins (ARE-BPs). To regulate mRNA metabolism, ARE-BPs bind target mRNAs and affect some factors on mRNAs directly, or recruit effectors, such as mRNA decay machinery and protein kinases to target mRNAs. Importantly, some ARE-BPs have stabilizing roles, whereas others are destabilizing, and ARE-BPs appear to compete with each other when binding to target mRNAs. The function of specific ARE-BPs is modulated by posttranslational modifications (PTMs) including methylation and phosphorylation, thereby providing a means for cellular signaling pathways to regulate stability of specific target mRNAs. In this review, we summarize recent studies which have revealed detailed molecular mechanisms of ARE-BP-mediated regulation of gene expression and also report on the importance of ARE-BP function in specific physiological contexts and how this relates to disease. We also propose an mRNP regulatory network based on competition between stabilizing ARE-BPs and destabilizing ARE-BPs.

Keywords: RNA-binding proteins, AU-rich element, ARE-binding proteins, translational control, mRNA decay

\section{INTRODUCTION}

Transcribed pre-mRNAs are subject to RNA processing in the nucleus, such as capping, polyadenylation, and splicing. Subsequently, processed mRNAs are exported to the cytoplasm (Bjork and Wieslander, 2017). In some cases, mRNAs are immediately translated, but they can also be transported to various subcellular compartments prior to translation. mRNAs are also turned over in the cytoplasm through regulated decay (Garneau et al., 2007). All of these posttranscriptional regulatory steps are important for proper gene expression and are themselves 
highly regulated. Interaction between RNA-binding proteins (RBPs) and specific cis-regulatory elements in target transcripts is the basis for most posttranscriptional regulation of gene expression (Figure 1; Moore, 2005).

Although there are a variety of cis-regulatory elements, for example, the cytoplasmic polyadenylated element (CPE) and the iron responsive element (IRE) (Charlesworth et al., 2013; Theil, 2015), we focus here on the AU-rich element (ARE), one important cis-element for RNA regulation, which is typically found in the mRNA 3' untranslated region (UTR). AREs are contained in $5-8 \%$ of human mRNAs coding factors involved in various biological functions such as proliferation, differentiation, signal transduction, apoptosis, and metabolism (Barreau et al., 2005; Bakheet et al., 2006). Originally identified as a sequence inducing mRNA decay (Chen and Shyu, 1995), the ARE was subsequently found to be more broadly involved in RNA processing, transport, and translation (Garcia-Maurino et al., 2017).

Many ARE-binding proteins (ARE-BPs) have been identified that bind to this element and mediate its function in posttranscriptional control (Table 1). Most ARE-BPs characterized to date recognize specific AREs in target mRNAs via canonical RNA-binding domains (RBDs), for example, the RNA recognition motif (RRM), CCCH tandem zinc finger domain, and $\mathrm{KH}$ domain (Hall, 2005; Clery et al., 2008; Nicastro et al., 2015). However, recently developed techniques have identified many new bona fide RBPs and revealed the surprising finding that about half of them do not have a conventional RBD (Castello et al., 2012; Beckmann et al., 2015, 2016). Intriguingly, these noncanonical RBPs include several ARE-BPs and analysis of their potentially contributions to ARE function is underway (Garcin, 2018).

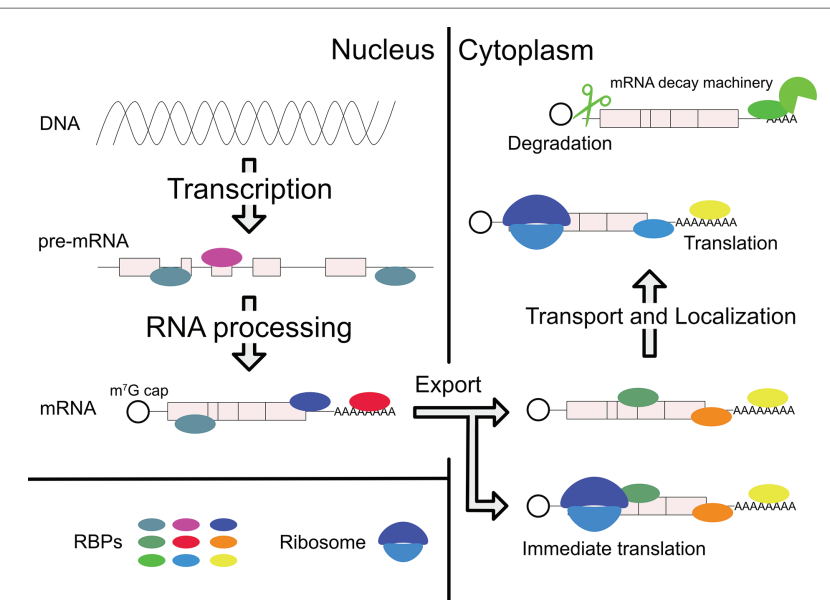

FIGURE 1 | Posttranscriptional regulations of gene expression by RBPs. After transcription, RBPs bind pre-mRNA and regulate RNA processing in the nucleus. Mature mRNA is transported to cytoplasm by other RBPs. In the cytoplasm, various RBPs control the different mRNA fates, which include localization, translation, and degradation. Collectively, these effects achieve proper gene expression within specific cell types and in response to specific biological regulatory signals. They can also lead to pathological conditions when regulation is compromised, for example, due to mutations in the gene encoding a specific RBP.
A common characteristic of many ARE-BPs is that they shuttle between nucleus and cytoplasm, but they exhibit different functions depending on their localization to control gene expression (Gama-Carvalho and Carmo-Fonseca, 2001). ARE-BP localization and function are both tightly regulated by posttranslational modifications (PTMs) and interactions with other factors (Chen and Shyu, 2014; Shen and Malter, 2015).

In this review, we summarize (1) the function of ARE-BPs to control mRNA stability or translation in the cytoplasm and RNA processing in the nucleus, (2) the biological and pathological importance of gene regulation by ARE-BPs, and (3) the regulation of ARE-BP function, particularly through PTM.

\section{MRNA STABILITY AND TRANSLATIONAL CONTROL BY ARE-BPS IN THE CYTOPLASM}

AUF1, also known as heterogeneous nuclear ribonucleoprotein D (hnRNP D), was the first identified ARE-BP that can destabilize mRNA (Brewer, 1991). AUF1-KO mice exhibit symptoms of severe endotoxic shock due to excessive production of tumor necrosis factor- $\alpha$ (TNF- $\alpha$ ) and interleukin-1 $\beta$ (IL-1 $\beta$ ), which results from failure to degrade these mRNAs (Lu et al., 2006b). AUF1 was also found to destabilize mRNAs encoding c-fos and c-myc (Brewer, 1991; Loflin et al., 1999), although another study reported that AUF1 stabilizes these mRNAs (Xu et al., 2001). These apparently conflicting results suggest that the function of AUF1 is not fixed, but can be differentially regulated depending on the cell type and specific conditions (Gouble et al., 2002). AUF1 forms the AUF1- and signal transductionregulated complex (ASTRC) with several factors [eIF4G, poly(A)-binding protein (PABP) C1, Hsp27, and Hsp70] (Laroia et al., 1999; Lu et al., 2006a; Sinsimer et al., 2008). This complex is required for AUF1-mediated mRNA decay, but its molecular mechanism of action is still unknown.

TTP is a destabilizing ARE-BP with a well-characterized molecular mechanism. This protein has a tandem zinc finger RBD and binds the $3^{\prime}$ UTR of mRNAs coding TNF- $\alpha$ and granulocyte macrophage colony-stimulating factor (GM-CSF), and induces mRNA decay (Lai et al., 1999; Lai and Blackshear, 2001). The mRNA coding for TTP also contains AREs in its 3'UTR, and thus, TTP regulates its own expression levels by a negative feedback (Brooks et al., 2004; Tchen et al., 2004). TTP recruits the CCR4-NOT complex to target mRNAs via direct binding to its subunits, CNOT1 and CNOT9 (Fabian et al., 2013; Bulbrook et al., 2018). TTP also interacts with the Dcp1a/Dcp2 complex involved in decapping and a component of the exosome, Rrp4, to degrade mRNA (Lykke-Andersen and Wagner, 2005). Furthermore, TTP represses translation by recruitment of 4EHP to target mRNAs through interaction between its PPPPG motif and GYF2 (Figure 2A; Tao and Gao, 2015; Fu et al., 2016). 4EHP has affinity for the $5^{\prime}$-end cap structure like eIF4E, but does not bind eIF4G. Therefore, 4EHP represses translation by competing with eIF4E for the cap (Morita et al., 2012). The TIS11 family, to which TTP belongs, also contains two other members, ZFP36L1 and ZFP36L2. 
TABLE 1 | The RBDs, targets, and functions of ARE-BPs in this review.

\begin{tabular}{|c|c|c|c|c|}
\hline \multicolumn{5}{|c|}{ The features of ARE-binding proteins } \\
\hline & $\begin{array}{l}\text { RNA-binding } \\
\text { domain }\end{array}$ & mRNA stabilization & mRNA destabilization & Other functions \\
\hline AUF1 & Four RRMs & c-fos, c-myc (Brewer, 1991) & $\begin{array}{l}\text { TNF- } \alpha, \text { IL-1 } \beta \text { (Lu et al., 2006b); } \\
\text { c-fos (Brewer, 1991); } \\
\text { c-myc (Loflin et al., 1999); } \\
\text { GM-CSF? (Pioli et al., 2002) }\end{array}$ & $\begin{array}{l}\text { Splicing (Fragkouli et al., 2017); } \\
\text { translational repression } \\
\text { (Fellows et al., 2013); } \\
\text { viral replication (Friedrich et al., 2014) }\end{array}$ \\
\hline TTP & $\begin{array}{l}\text { Tandem zinc } \\
\text { finger domains }\end{array}$ & & $\begin{array}{l}\text { TNF- } \alpha \text { (Lai and Blackshear, 2001; Su et al., 2012); } \\
\text { GM-CSF (Lai et al., 1999; Su et al., 2012); } \\
\text { TTP (Brooks et al., 2004; Tchen et al., 2004); } \\
\text { IL-10 (Su et al., 2012) }\end{array}$ & $\begin{array}{l}\text { Translational repression (Tao and Gao, 2015; } \\
\qquad \text { Fu et al., 2016) }\end{array}$ \\
\hline ZFP36L1 & $\begin{array}{l}\text { Tandem zinc } \\
\text { finger domains }\end{array}$ & & $\begin{array}{l}\text { DIl4 (Desroches-Castan et al., 2011); } \\
\text { CDK6 (Chen et al., 2015) }\end{array}$ & \\
\hline ZFP36L2 & $\begin{array}{l}\text { Tandem zinc } \\
\text { finger domains }\end{array}$ & & $\begin{array}{c}\text { LHR (Ball et al., 2017); } \\
\text { H3K4, H3K9 (Dumdie et al., 2018) }\end{array}$ & \\
\hline KSRP & $\begin{array}{l}\text { Four KH } \\
\text { domains }\end{array}$ & & Myogenin (Giovarelli et al., 2014) & $\begin{array}{c}\text { Viral translation repression (Lin et al., 2009); } \\
\text { miRNA maturation (Ruggiero et al., 2009; } \\
\text { Trabucchi et al., 2009); } \\
\text { splicing (Min et al., 1997) }\end{array}$ \\
\hline HuR & Three RRMs & $\begin{array}{c}\text { C-fos, cox2, TNF- } \alpha \\
\text { (Katsanou et al., 2005); } \\
\text { SIRT1 (Calvanese et al., 2010) }\end{array}$ & & $\begin{array}{l}\text { Translational control in neocortex } \\
\text { (Kraushar et al., 2014) }\end{array}$ \\
\hline $\begin{array}{l}\text { Nuronal Hu } \\
\text { proteins }\end{array}$ & Three RRMs & $\begin{array}{l}\text { GAP-43 (Mobarak et al., 2000); } \\
\text { APP, BACE1 (Kang et al., 2014) }\end{array}$ & HuR (Mansfield and Keene, 2012) & $\begin{array}{l}\text { Splicing (Fragkouli et al., 2017); } \\
\text { translation stimulation (Fukao et al., 2009); } \\
\text { miRNA attenuation (Fukao et al., 2014) }\end{array}$ \\
\hline GAPDH & $\begin{array}{l}\text { Rossmann } \\
\text { fold }\end{array}$ & CSF-1 (Zhou et al., 2008) & $\begin{array}{c}\text { Cox-2 (Ikeda et al., 2012); } \\
\text { ET-1 (Rodriguez-Pascual et al., 2008) }\end{array}$ & Translational repression (Chang et al., 2013) \\
\hline LDHM & $\begin{array}{l}\text { Rossmann } \\
\text { fold }\end{array}$ & & GM-CSF? (Pioli et al., 2002) & Interaction with AUF1 (Pioli et al., 2002) \\
\hline
\end{tabular}

Blue colors show canonical ARE-BPs, and red color shows noncanonical ARE-BPS.

Although these factors differ from each other in their tissue distribution and target mRNAs, they have about 70\% homology, including the CNOT1 binding site, and both induce mRNA decay (Sanduja et al., 2011).

K-homology splicing regulatory protein (KSRP) was initially identified as a nuclear factor involved in transcription and splicing (Davis-Smyth et al., 1996; Min et al., 1997). Subsequently, it was reported that KSRP binds the ARE using two of four KH domains, KH3 and KH4 (Gherzi et al., 2004), and destabilizes target mRNAs by recruitment of poly(A)-specific ribonuclease (PARN) and exosome to mRNAs (Chen et al., 2001; Chou et al., 2006). Furthermore, it was shown that KSRP interacts with the enterovirus 71 internal ribosomal entry site (IRES) and behaves as an IRES trans-acting factor (ITAF) to negatively regulate viral translation (Lin et al., 2009).

Unlike the ARE-BPs introduced so far, Hu proteins are ARE-BPs that stabilize their target mRNAs. The Hu protein family consists of four members. HuR is ubiquitously expressed, whereas $\mathrm{HuB}$, $\mathrm{HuC}$, and $\mathrm{HuD}$ are mainly expressed in neurons. All members of $\mathrm{Hu}$ proteins have three RRMs. RRM1 and RRM2 recognize ARE, and RRM3 binds the poly(A) tail (Ma et al., 1997). HuR binds to the ARE in the mRNAs encoding c-fos, Cox 2, and TNF- $\alpha$ in competition with TTP or KSRP and stabilizes these mRNAs (Fan and Steitz, 1998b; Katsanou et al., 2005). Furthermore, 

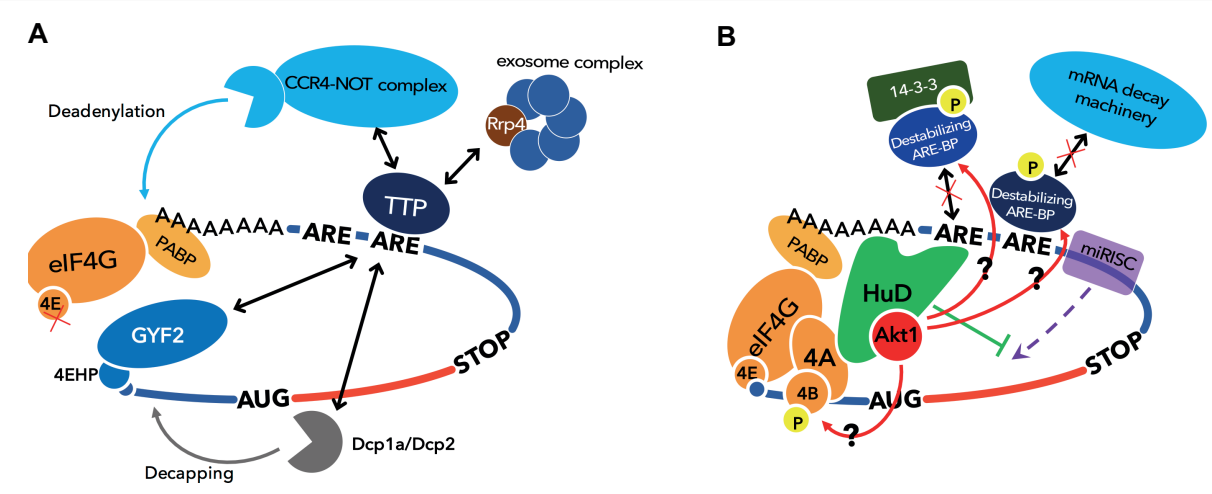

FIGURE 2 | Functional model of destabilizing ARE-BP, TTP and stabilizing ARE-BP, HuD. (A) TTP induces mRNA decay by recruiting CCR4-NOT complex, exosome complex, and Dcp1a/Dcp2 complex and represses translation by recruiting 4EHP via binding GYF2. (B) HuD stimulates translation via direct binding to elF4A and the poly(A) tail. miRISC represses translation by dissociation of elF4A from the translation initiation complex, and this inhibitory effect on translation initiation is attenuated by HuD. HuD also binds Akt/PKB, which phosphorylates destabilizing ARE-BPs such as KSRP, TTP, ZFP36L1, and ZFP36L2 to inactivate them, and elF4B to stimulate helicase activity of elF4A.

HuR associates with eIF2 alpha kinase 4 and may temporally define translation in the developing neocortex (Kraushar et al., 2014). Neuronal $\mathrm{Hu}$ proteins are thought to regulate and induce neuronal differentiation through stabilizing target mRNAs (Okano and Darnell, 1997; Mobarak et al., 2000; Akamatsu et al., 2005). Fukao et al. previously showed that $\mathrm{HuD}$ stimulates translation initiation via direct binding to the poly(A) tail and eIF4A (Fukao et al., 2009). Furthermore, Fujiwara et al. demonstrated that physical interaction between $\mathrm{HuD}$ and the active form of Akt/ $\mathrm{PKB}$ is required for morphological alterations such as neurite outgrowth in PC12 cells undergoing a neuronal differentiation program (Fujiwara et al., 2012). Akt/PKB directly phosphorylates eIF4B, whose phosphorylation stimulates the RNA helicase activity of eIF4A (Rozen et al., 1990; Altmann et al., 1993; van Gorp et al., 2009). Thus, it is possible that $\mathrm{HuD}$ recruits Akt/PKB to the translation initiation complex to stimulate eIF4A activity on its ARE-containing mRNAs (Figure 2B).

\section{NUCLEAR FUNCTION OF ARE-BPS}

Regulation of mRNA stability, localization, and translation is a cytoplasmic function of ARE-BPs, yet most ARE-BPs shuttle between nucleus and cytoplasm, thereby suggesting that these proteins also have nuclear functions. Indeed, several nuclear functions for ARE-BPs have been identified. For example, in recent years, it was shown that KSRP has a novel nuclear function involved in maturation of a subset of microRNAs (Ruggiero et al., 2009; Trabucchi et al., 2009). KSRP binds to a terminal loop of miRNA precursors and promotes both steps of biogenesis: conversion of pri-miRNAs to pre-miRNAs in the nucleus by Drosha and pre-miRNA processing to mature miRNAs in the cytoplasm by Dicer (Trabucchi et al., 2009).

$\mathrm{Hu}$ proteins have a domain regulating nuclear-cytoplasmic shuttling located in a linker region between RRM2 and RRM3 (Fan and Steitz, 1998a; Kasashima et al., 1999). A recent study showed that AREs are abundant in introns of human genes and that $\mathrm{HuR}$ regulates expression of genes containing these intronic AREs (Bakheet et al., 2018). The pre-mRNAs coding for HuR undergo alternative polyadenylation leading to transcript variants with different lengths of $3^{\prime}$ UTR and stability (Al-Ahmadi et al., 2009). Because HuR impairs neuronal differentiation by promoting cell proliferation, neuronal $\mathrm{Hu}$ proteins decrease $\mathrm{HuR}$ expression by binding to the pre-mRNA of $\mathrm{HuR}$ at the polyadenylation site to produce a less stable mRNA bearing the long 3'UTR (Mansfield and Keene, 2012). Neuronal Hu proteins are also involved in neuron-specific alternative splicing by utilizing AUF1 as a co-factor (Fragkouli et al., 2017).

TIS11 family proteins have a potential nuclear localization signal within the zinc finger domain (Murata et al., 2002; Phillips et al., 2002; Twyffels et al., 2013). In the nucleus, TTP in association with poly(A)-binding protein nuclear 1 (PABPN1) inhibits poly(A) tail synthesis on mRNAs which contain AREs, such as TNF- $\alpha$, GM-CSF, and IL-10, thereby promoting degradation of these transcripts (Su et al., 2012). Under hypoxia, ZFP36L1 has been reported to reduce expression level of Deltalike 4 (Dll4) involved in cell fate determination in angiogenesis by inhibiting cleavage at the polyadenylation site of the Dll4 mRNA (Kume, 2009; Desroches-Castan et al., 2011).

\section{NONCANONICAL ARE-BPs}

Recently, systematic investigation of RBPs has been performed in various cell types (yeast and cultured cells) by interactome capture assays (Castello et al., 2012; Beckmann et al., 2015, 2016). Protein-RNA interactions are immobilized by conventional UV crosslinking (cCL) by $254 \mathrm{~nm}$ UV irradiation or photoactivatable ribonucleoside-enhanced (PAR-) CL by $365 \mathrm{~nm}$ UV irradiation using cells by which photoactivatable 4-thiouridine (4 SU) is taken up. Then, mRNA-RBP complexes are captured by oligo(dT) beads, and the proteins are analyzed by mass 
spectrometry after digestion of mRNAs. As a result, many novel RBPs were detected. Surprisingly, about half of these have no conventional RBD (Castello et al., 2012; Beckmann et al., 2015, 2016). Many well-known metabolic enzymes are among these noncanonical RBPs. A typical example of a metabolic enzyme that has been identified as noncanonical $\mathrm{RBP}$ is ACO1/IRP1. When iron levels are in the normal physiological range, ACO1/IRP1 functions as a cytoplasmic aconitase in the TCA cycle. However, in iron-deficient conditions, ACO1/IRP1 behaves as a sequence-specific RBP that recognizes a certain stem-loop structure, the iron-responsive element (IRE) (Constable et al., 1992). ACO1/IRP1 binds the 3'UTR of the mRNA coding transferrin involved in iron uptake and stabilizes this mRNA (Casey et al., 1988; Mullner and Kuhn, 1988). It also binds to an IRE in the 5'UTR of the mRNA encoding ferritin, a protein involved in iron storage. In this case, it inhibits translation (Hentze et al., 1987), thereby regulating the intracellular iron level. This classic example of a metabolic enzyme moonlighting as an RBP illustrates how cellular metabolic states can be intimately connected with posttranscriptional regulation of gene expression (Castello et al., 2015).

Further evidence to support this principle is found in the glycolytic enzyme, glyceraldehyde-3-phosphate dehydrogenase (GAPDH), which is a noncanonical ARE-BP (Nagy and Rigby, 1995). GAPDH binds the ARE via a Rossmann fold which binds $\mathrm{NAD}^{+} / \mathrm{NADH}$, and thus, $\mathrm{NAD}^{+}$abundance affects binding activity of GAPDH to the ARE (Nagy and Rigby, 1995; Rodriguez-Pascual et al., 2008; Ikeda et al., 2012). Indeed, a switch from oxidative phosphorylation to aerobic glycolysis when $\mathrm{T}$ lymphocytes are activated promotes dissociation of GAPDH from the ARE in the mRNA coding for interferon- $\gamma$ $(I F N-\gamma)$ and increases expression of IFN- $\gamma$ (Chang et al., 2013). GAPDH also binds to mRNAs containing AREs, such as those encoding colony stimulating factor-1 (CSF-1), cyclooxygenase-2 (Cox-2), and endothelin-1 (ET-1), and regulates stability or translation of these mRNAs (RodriguezPascual et al., 2008; Zhou et al., 2008; Ikeda et al., 2012). Likewise, lactate dehydrogenase ( $\mathrm{LDH}) \mathrm{M}$, which is a glycolytic enzyme, also binds an ARE in the mRNA coding for GM-CSF by a Rossmann fold in an $\mathrm{NAD}^{+}$concentration-dependent manner (Pioli et al., 2002). Moreover, LDHM directly interacts with AUF1. This interaction is thought to complement low binding specificity of AUF1, which also binds various RNAs even without AREs (Kiledjian et al., 1997; Eversole and Maizels, 2000), and to be utilized for recruitment of AUF1 to target mRNAs (Pioli et al., 2002).

\section{BIOLOGICAL FUNCTIONS OF ARE-BPS IN HEALTH AND DISEASE}

The fact that AREs are found mainly in mRNAs coding for inflammatory cytokines and growth factors suggests the potential for coordinated regulation of specific biological processes by ARE-BPs (Barreau et al., 2005; Khabar, 2017; Turner and Diaz-Munoz, 2018).
ZFP36L1 and ZFP36L2 have redundant functions in T-cell and B-cell maturation (Hodson et al., 2010; Galloway et al., 2016). During T-cell maturation, ZFP36L1 and ZFP36L2 limit the cell cycle and repress the DNA damage response induced by double-strand DNA breaks (Vogel et al., 2016). Moreover, ZFP36L1 promotes monocyte/macrophage differentiation by controlling mRNA stability of CDK6 (Chen et al., 2015). It was reported that mice that lack the N-terminal 29 amino acids of ZFP36L2 are infertile (Ramos et al., 2004; Ramos, 2012), due to failure to control expression of luteinizing hormone receptor (LHR) by ZFP36L2 (Ball et al., 2014). More recently, oocyte-specific KO of ZFP36L2 in mice showed that this protein controls expression of histone demethylases targeting $\mathrm{H} 3 \mathrm{~K} 4$ and $\mathrm{H} 3 \mathrm{~K} 9$ and induces global transcriptional silencing in the oocyte, which is important for the oocyte-to-embryo transition (Dumdie et al., 2018).

Neuronal $\mathrm{Hu}$ proteins are involved in alternative splicing of amyloid precursor protein (APP) (Fragkouli et al., 2017). The APP gene contains 18 exons and 3 isoforms: APP770 contains all exons, APP751 lacks exon 8, and APP695 lacks exons 7 and 8. In the brain of Alzheimer's disease patients, APP695 is decreased, whereas APP770 is increased (Moir et al., 1998; Matsui et al., 2007). Neuronal $\mathrm{Hu}$ proteins promote expression of APP695 instead of APP770 (Fragkouli et al., 2017). On the other hand, HuD stabilizes the mRNAs for APP, as well as $\beta$-site APP-cleaving enzyme 1 (BACE1), which induces processing from APP to amyloid- $\beta$ (Kang et al., 2014).

ARE-BPs are also implicated in other neurological disorders. A human genetics study identified TIA1 mutations in amyotrophic lateral sclerosis (ALS) and frontotemporal dementia (FTD) patients (Mackenzie et al., 2017). Interestingly, this same study showed that these mutations promote phase separation of TIA1 protein and affect the dynamics of stress granules, which are themselves suggested to be important in ALS pathology (Li et al., 2013; Zhang et al., 2018).

$\mathrm{HuD}$ may also be involved in ALS and another neurological disorder, spinal muscular atrophy (SMA). Direct evidence for a contribution of $\mathrm{HuD}$ to ALS is lacking, but it was found to form insoluble aggregates in the cytoplasm with TDP-43, an RBP heavily implicated in ALS and FTD (Fallini et al., 2011), thereby raising the possibility of pathological interactions between these two RBPs. In addition to nuclear functions in pre-mRNA processing, TDP-43 also represses translation of specific mRNAs in Drosophila ALS models and cultured mammalian cells (Majumder et al., 2012, 2016; Coyne et al., 2014, 2017), although the exact connection between these mRNAs and ALS remains unclear. More recently, TDP-43 was also shown to function as an mRNA-specific translational enhancer for the mRNAs encoding CAMTA1 and DENND4, both of which are directly linked to ALS and neurodegenerative disease (Neelagandan et al., 2019). Whether HuD contributes to this regulation remains to be determined. However, the Camtal and Dennd4a mRNAs both contain many AREs based on in silico analyses (Fallmann et al., 2016). This observation, taken together with HuD's ability to function as an mRNAspecific translational enhancer via AREs (Fukao et al., 2009), 
raises the possibility that $\mathrm{HuD}$ might potentially function as a co-factor in TDP-43-driven translational enhancement of Camtal and Dennd4a mRNAs.

SMA is caused by lack or mutation of survival of motor neuron protein (SMN) (Burghes and Beattie, 2009). SMN interacts with $\mathrm{HuD}$ on mRNAs such as the one coding for candidate plasticity-related gene 15 (cpg15), and forms an RNA granule (Akten et al., 2011; Fallini et al., 2011; Hubers et al., 2011). The tudor domain of SMN is important for interaction between SMN and $\mathrm{HuD}$, and an SMN mutant from severe SMA patients bearing a mutation in the Tudor domain cannot interact with $\mathrm{HuD}$ (Buhler et al., 1999; Fallini et al., 2011; Hubers et al., 2011). What does this interaction between HuD and SMN mean? We previously reported translation stimulation by $\mathrm{HuD}$ (Fukao et al., 2009). Another group showed that SMN represses translation of certain mRNAs, and the Tudor domain mutant of SMN is not able to repress translation (Sanchez et al., 2013). Repression of ectopic translation and induction of translation initiation in response to local stimulatory cues are important components of local translation in neuronal compartments. Moreover, SMN is closely involved in axonal translation (Bernabo et al., 2017). Therefore, an interesting possibility is that $\mathrm{SMN}$ and $\mathrm{HuD}$ could have opposite, but complementary, roles in the context of neuronal mRNP transport and translation. According to this view, SMN could function as a brake to suppress ectopic translation while mRNPs are transported to sites where local protein synthesis would occur. Conversely, HuD's role would be to promote translation initiation at these sites in response to local neuronal cues. Future studies in primary neuronal cultures could examine this possibility.

\section{REGULATION OF ARE-BP FUNCTION}

As can be seen from the examples of $\mathrm{SMN}$ and $\mathrm{HuD}$, functional regulation of ARE-BPs is strongly related to biological functions and diseases. Thus, function of ARE-BPs is controlled by several factors such as long noncoding (lnc) RNA, other proteins, and PTMs.

H19 is an lncRNA expressed in embryo and skeletal muscle (Bartolomei et al., 1991). A recent study showed that H19 directly binds KSRP and promotes destabilization of the mRNA for myogenin by KSRP, thus favoring myogenic differentiation (Giovarelli et al., 2014). Overexpressed in colon carcinoma-1 (OCC-1), an lncRNA binds HuR and enhances binding of the $\beta$-TrCP1 E3-ubiquitin ligase, thereby promoting destabilization of the HuR protein (Pibouin et al., 2002; Lan et al., 2018).

Arginine methylation is a common feature of a large population of RGG box proteins, which are involved in many aspects of mRNA metabolism (Rajyaguru and Parker, 2012). In some cases, arginine methylation has been shown to regulate the function of ARE-BPs containing RGG boxes. For example, HuR is methylated at R217 by coactivator-associated arginine methyltransferase 1 (CARM1) and methylated HuR binds the mRNA encoding the histone deacetylase, Sirtuin 1 (SIRT1) to stabilize it (Calvanese et al., 2010). Many hnRNP proteins that contain RGG boxes are also subject to arginine methylation, thereby potentially affecting their localization and RNA-binding activity (Yu, 2011). However, while it was reported that hnRNP D/AUF1 is methylated, this did not seem to affect either localization or RNA-binding activity of AUF1 (DeMaria et al., 1997; Sarkar et al., 2003). Recently, it was shown that arginine methylation of AUF1 is involved in translational repression of the mRNA coding for vascular endothelial growth factor (VEGF) (Fellows et al., 2013). Furthermore, this PTM also affects AUF1's role as a host factor during the replication of the West Nile virus genome (Friedrich et al., 2014) In this case, arginine methylation of AUF1 by protein arginine $\mathrm{N}$-methyltransferase 1 (PRMT1) promotes AUF1 function as an RNA chaperone (Friedrich et al., 2016).

Many ARE-BPs are phosphorylated. In some cases, the regulatory effects of phosphorylation, as well as the signaling pathways and kinases responsible, have been determined. For example, KSRP has two independent phosphorylation sites in its C-terminal and KH1 domains (Briata et al., 2005; DiazMoreno et al., 2009). The C-terminal Thr692 of KSRP is phosphorylated by $\mathrm{p} 38 / \mathrm{MAPK}$ to promote destabilization of target mRNAs (Briata et al., 2005). On the other hand, Ser193 in the $\mathrm{KH} 1$ domain is phosphorylated by Akt/PKB to localize KSRP in the nucleus via binding of 14-3-3 proteins, thereby inhibiting mRNA decay in the cytoplasm (Diaz-Moreno et al., 2009). TIS11 family proteins, TTP, and ZFP36L1 and ZFP36L2 are also phosphorylated by $\mathrm{p} 38 / \mathrm{MAPK}$ or $\mathrm{Akt} / \mathrm{PKB}$ and recognized by 14-3-3 proteins (Chrestensen et al., 2004; Schmidlin et al., 2004; Benjamin et al., 2006). Phosphorylation of TTP at Ser52 and Ser178 reduces interaction with the CCR4-NOT complex and thereby upregulates mRNA stability (Marchese et al., 2010). Conversely, phosphorylation at Ser334 of ZFP36L1 also decreases interaction with the CCR4-NOT complex, but increases affinity to Dcpla to promote mRNA decay (Rataj et al., 2016).

$\mathrm{HuD}$ is subject to phosphorylation by $\mathrm{PKC}$ to promote its mRNA stabilizing activity (Lim and Alkon, 2012). On the other hand, we previously demonstrated that $\mathrm{HuD}$ interacts with Akt/PKB, although Akt/PKB does not lead to $\mathrm{HuD}$ phosphorylation (Fujiwara et al., 2012). This interaction might recruit Akt/PKB, which phosphorylates and inactivates destabilizing ARE-BPs such as KSRP and TIS11 family proteins, to ARE-containing mRNAs. This suggests that $\mathrm{HuD}$ can not only compete with destabilizing ARE-BPs but also potentially inactivate them on the same mRNA through phosphorylation by Akt/PKB to stabilize mRNA. We also showed that $\mathrm{HuD}$ attenuates translational repression by the miRNA-induced silencing complex (miRISC), which leads to mRNA decay as well as destabilizing ARE-BPs (Fukao et al., 2014). These observations support a central role for $\mathrm{HuD}$ in stabilizing mRNA and promoting translation (Figure 2B).

\section{CONCLUSION AND PERSPECTIVES}

The ARE has been studied for a long time, and about 20 ARE-BPs have been identified since discovery of first ARE-BP, AUF1 (Brewer, 1991; Garcia-Maurino et al., 2017). The specific target mRNAs for different ARE-BPs, as well as their molecular 
functions on these mRNAs, and contribution of this regulation to specific biological processes are gradually being uncovered. However, with a few exceptions, the molecular mechanisms used by ARE-BPs to regulate their targets are still unknown. In particular, the mechanism to recognize and control specific targets from the large number of transcripts that have AREs is an open question. Recently, Ball et al. revealed that ZFP36L2, but not ZFP36L1, recognizes one of three AREs in $3^{\prime} \mathrm{UTR}$ of mRNA coding LHR, and this ARE is located within a hairpin structure (Ball et al., 2014, 2017). This indicates that not only the ARE sequence but also proximal RNA secondary structure affects the binding specificity of ARE-BPs. Future experimental and in silico approaches to understand the determinants of ARE recognition by specific ARE-BPs' analysis will thus be needed to incorporate RNA structure, as well as sequence. Moreover,

\section{REFERENCES}

Akamatsu, W., Fujihara, H., Mitsuhashi, T., Yano, M., Shibata, S., Hayakawa, Y., et al. (2005). The RNA-binding protein HuD regulates neuronal cell identity and maturation. Proc. Natl. Acad. Sci. USA 102, 4625-4630. doi: 10.1073/ pnas.0407523102

Akten, B., Kye, M. J., Hao le, T., Wertz, M. H., Singh, S., Nie, D., et al. (2011). Interaction of survival of motor neuron (SMN) and $\mathrm{HuD}$ proteins with mRNA cpg15 rescues motor neuron axonal deficits. Proc. Natl. Acad. Sci. USA 108, 10337-10342. doi: 10.1073/pnas.1104928108

Al-Ahmadi, W., Al-Ghamdi, M., Al-Haj, L., Al-Saif, M., and Khabar, K. S. (2009). Alternative polyadenylation variants of the RNA binding protein, HuR: abundance, role of AU-rich elements and auto-Regulation. Nucleic Acids Res. 37, 3612-3624. doi: 10.1093/nar/gkp223

Altmann, M., Muller, P. P., Wittmer, B., Ruchti, F., Lanker, S., and Trachsel, H. (1993). A Saccharomyces cerevisiae homologue of mammalian translation initiation factor $4 \mathrm{~B}$ contributes to RNA helicase activity. $E M B O$ J. 12, 3997-4003. doi: 10.1002/j.1460-2075.1993.tb06077.x

Bakheet, T., Hitti, E., Al-Saif, M., Moghrabi, W. N., and Khabar, K. S. A. (2018). The AU-rich element landscape across human transcriptome reveals a large proportion in introns and regulation by ELAVL1/HuR. Biochim. Biophys. Acta 1861, 167-177. doi: 10.1016/j.bbagrm.2017.12.006

Bakheet, T., Williams, B. R., and Khabar, K. S. (2006). ARED 3.0: the large and diverse AU-rich transcriptome. Nucleic Acids Res. 34, D111-D114. doi: 10.1093/nar/gkj052

Ball, C. B., Rodriguez, K. F., Stumpo, D. J., Ribeiro-Neto, F., Korach, K. S., Blackshear, P. J., et al. (2014). The RNA-binding protein, ZFP36L2, influences ovulation and oocyte maturation. PLoS One 9:e97324. doi: 10.1371/journal. pone.0097324

Ball, C. B., Solem, A. C., Meganck, R. M., Laederach, A., and Ramos, S. B. V. (2017). Impact of RNA structure on ZFP36L2 interaction with luteinizing hormone receptor mRNA. RNA 23, 1209-1223. doi: 10.1261/rna.060467.116

Barreau, C., Paillard, L., and Osborne, H. B. (2005). AU-rich elements and associated factors: are there unifying principles? Nucleic Acids Res. 33, 7138-7150. doi: 10.1093/nar/gki1012

Bartolomei, M. S., Zemel, S., and Tilghman, S. M. (1991). Parental imprinting of the mouse H19 gene. Nature 351, 153-155. doi: 10.1038/351153a0

Beckmann, B. M., Castello, A., and Medenbach, J. (2016). The expanding universe of ribonucleoproteins: of novel RNA-binding proteins and unconventional interactions. Pflugers Arch. 468, 1029-1040. doi: 10.1007/s00424-016-1819-4

Beckmann, B. M., Horos, R., Fischer, B., Castello, A., Eichelbaum, K., Alleaume, A. M., et al. (2015). The RNA-binding proteomes from yeast to man harbour conserved enigmRBPs. Nat. Commun. 6:10127. doi: 10.1038/ ncomms 10127

Benjamin, D., Schmidlin, M., Min, L., Gross, B., and Moroni, C. (2006). BRF1 protein turnover and mRNA decay activity are regulated by protein kinase B at the same phosphorylation sites. Mol. Cell. Biol. 26, 9497-9507. doi: 10.1128/ MCB.01099-06 as shown in the example of LDHM and AUF1 (Pioli et al., 2002), it will also be necessary to study the influence of the interaction between ARE-BPs on specific ARE recognition and molecular regulatory mechanisms on the same transcripts. Finally, systematic studies have shown that the relative spacing of $3^{\prime} \mathrm{UTR}$ cis-elements and associated regulatory proteins can have strong contextual effects on regulation (Pique et al., 2008). Thus, to understand fully ARE-BP function and mechanism, it will be important to examine interplay between AREs, ARE-BPs, and other neighboring cis-elements within specific $3^{\prime}$ UTRs.

\section{AUTHOR CONTRIBUTIONS}

$\mathrm{HO}, \mathrm{AF}, \mathrm{YF}, \mathrm{KD}$, and TF wrote and discussed the article.

Bernabo, P., Tebaldi, T., Groen, E. J. N., Lane, F. M., Perenthaler, E., Mattedi F., et al. (2017). In Vivo Translatome Profiling in Spinal Muscular Atrophy Reveals a Role for SMN Protein in Ribosome Biology. Cell Rep. 21, 953-965. doi: 10.1016/j.celrep.2017.10.010

Bjork, P., and Wieslander, L. (2017). Integration of mRNP formation and export. Cell. Mol. Life Sci. 74, 2875-2897. doi: 10.1007/s00018-017-2503-3

Brewer, G. (1991). An A + U-rich element RNA-binding factor regulates c-myc mRNA stability in vitro. Mol. Cell. Biol. 11, 2460-2466. doi: 10.1128/MCB.11.5.2460

Briata, P., Forcales, S. V., Ponassi, M., Corte, G., Chen, C. Y., Karin, M., et al. (2005). p38-dependent phosphorylation of the mRNA decay-promoting factor KSRP controls the stability of select myogenic transcripts. Mol. Cell 20, 891-903. doi: 10.1016/j.molcel.2005.10.021

Brooks, S. A., Connolly, J. E., and Rigby, W. F. (2004). The role of mRNA turnover in the regulation of tristetraprolin expression: evidence for an extracellular signal-regulated kinase-specific, AU-rich element-dependent, autoregulatory pathway. J. Immunol. 172, 7263-7271. doi: 10.4049/jimmunol.172.12.7263

Buhler, D., Raker, V., Luhrmann, R., and Fischer, U. (1999). Essential role for the tudor domain of SMN in spliceosomal U snRNP assembly: implications for spinal muscular atrophy. Hum. Mol. Genet. 8, 2351-2357. doi: 10.1093/ hmg/8.13.2351

Bulbrook, D., Brazier, H., Mahajan, P., Kliszczak, M., Fedorov, O., Marchese, F. P., et al. (2018). Tryptophan-mediated interactions between tristetraprolin and the CNOT9 subunit are required for CCR4-NOT deadenylase complex recruitment. J. Mol. Biol. 430, 722-736. doi: 10.1016/j.jmb.2017.12.018

Burghes, A. H., and Beattie, C. E. (2009). Spinal muscular atrophy: why do low levels of survival motor neuron protein make motor neurons sick? Nat. Rev. Neurosci. 10, 597-609. doi: 10.1038/nrn2670

Calvanese, V., Lara, E., Suarez-Alvarez, B., Abu Dawud, R., Vazquez-Chantada, M., Martinez-Chantar, M. L., et al. (2010). Sirtuin 1 regulation of developmental genes during differentiation of stem cells. Proc. Natl. Acad. Sci. USA 107, 13736-13741. doi: 10.1073/pnas.1001399107

Casey, J. L., Hentze, M. W., Koeller, D. M., Caughman, S. W., Rouault, T. A., Klausner, R. D., et al. (1988). Iron-responsive elements: regulatory RNA sequences that control mRNA levels and translation. Science 240, 924-928. doi: $10.1126 /$ science. 2452485

Castello, A., Fischer, B., Eichelbaum, K., Horos, R., Beckmann, B. M., Strein, C., et al. (2012). Insights into RNA biology from an atlas of mammalian mRNAbinding proteins. Cell 149, 1393-1406. doi: 10.1016/j.cell.2012.04.031

Castello, A., Hentze, M. W., and Preiss, T. (2015). Metabolic enzymes enjoying new partnerships as RNA-binding proteins. Trends Endocrinol. Metab. 26, 746-757. doi: 10.1016/j.tem.2015.09.012

Chang, C. H., Curtis, J. D., Maggi, L. B. Jr., Faubert, B., Villarino, A. V., O'Sullivan, D., et al. (2013). Posttranscriptional control of $\mathrm{T}$ cell effector function by aerobic glycolysis. Cell 153, 1239-1251. doi: 10.1016/j.cell.2013.05.016

Charlesworth, A., Meijer, H. A., and de Moor, C. H. (2013). Specificity factors in cytoplasmic polyadenylation. Wiley Interdiscip. Rev. RNA 4, 437-461. doi: 10.1002/wrna.1171 
Chen, M. T., Dong, L., Zhang, X. H., Yin, X. L., Ning, H. M., Shen, C., et al. (2015). ZFP36L1 promotes monocyte/macrophage differentiation by repressing CDK6. Sci. Rep. 5:16229. doi: 10.1038/srep16229

Chen, C. Y., Gherzi, R., Ong, S. E., Chan, E. L., Raijmakers, R., Pruijn, G. J., et al. (2001). AU binding proteins recruit the exosome to degrade AREcontaining mRNAs. Cell 107, 451-464. doi: 10.1016/S0092-8674(01)00578-5

Chen, C. Y., and Shyu, A. B. (1995). AU-rich elements: characterization and importance in mRNA degradation. Trends Biochem. Sci. 20, 465-470. doi: 10.1016/S0968-0004(00)89102-1

Chen, C. Y., and Shyu, A. B. (2014). Emerging mechanisms of mRNP remodeling regulation. Wiley Interdiscip. Rev. RNA 5, 713-722. doi: 10.1002/wrna.1241

Chou, C. F., Mulky, A., Maitra, S., Lin, W. J., Gherzi, R., Kappes, J., et al. (2006). Tethering KSRP, a decay-promoting AU-rich element-binding protein, to mRNAs elicits mRNA decay. Mol. Cell. Biol. 26, 3695-3706. doi: 10.1128/ MCB.26.10.3695-3706.2006

Chrestensen, C. A., Schroeder, M. J., Shabanowitz, J., Hunt, D. F., Pelo, J. W., Worthington, M. T., et al. (2004). MAPKAP kinase 2 phosphorylates tristetraprolin on in vivo sites including Ser178, a site required for 14-3-3 binding. J. Biol. Chem. 279, 10176-10184. doi: 10.1074/jbc.M310486200

Clery, A., Blatter, M., and Allain, F. H. (2008). RNA recognition motifs: boring? Not quite. Curr. Opin. Struct. Biol. 18, 290-298. doi: 10.1016/j. sbi.2008.04.002

Constable, A., Quick, S., Gray, N. K., and Hentze, M. W. (1992). Modulation of the RNA-binding activity of a regulatory protein by iron in vitro: switching between enzymatic and genetic function? Proc. Natl. Acad. Sci. USA 89, 4554-4558. doi: 10.1073/pnas.89.10.4554

Coyne, A. N., Lorenzini, I., Chou, C. C., Torvund, M., Rogers, R. S., Starr, A., et al. (2017). Post-transcriptional inhibition of Hsc70-4/HSPA8 expression leads to synaptic vesicle cycling defects in multiple models of ALS. Cell Rep. 21, 110-125. doi: 10.1016/j.celrep.2017.09.028

Coyne, A. N., Siddegowda, B. B., Estes, P. S., Johannesmeyer, J., Kovalik, T., Daniel, S. G., et al. (2014). Futsch/MAP1B mRNA is a translational target of TDP-43 and is neuroprotective in a Drosophila model of amyotrophic lateral sclerosis. J. Neurosci. 34, 15962-15974. doi: 10.1523/ JNEUROSCI.2526-14.2014

Davis-Smyth, T., Duncan, R. C., Zheng, T., Michelotti, G., and Levens, D. (1996). The far upstream element-binding proteins comprise an ancient family of single-strand DNA-binding transactivators. J. Biol. Chem. 271, 31679-31687. doi: 10.1074/jbc.271.49.31679

DeMaria, C. T., Sun, Y., Long, L., Wagner, B. J., and Brewer, G. (1997). Structural determinants in AUF1 required for high affinity binding to A + U-rich elements. J. Biol. Chem. 272, 27635-27643. doi: 10.1074/jbc.272.44.27635

Desroches-Castan, A., Cherradi, N., Feige, J. J., and Ciais, D. (2011). A novel function of Tis11b/BRF1 as a regulator of Dll4 mRNA $3^{\prime}$-end processing. Mol. Biol. Cell 22, 3625-3633. doi: 10.1091/mbc.e11-02-0149

Diaz-Moreno, I., Hollingworth, D., Frenkiel, T. A., Kelly, G., Martin, S., Howell, S., et al. (2009). Phosphorylation-mediated unfolding of a KH domain regulates KSRP localization via 14-3-3 binding. Nat. Struct. Mol. Biol. 16, 238-246. doi: $10.1038 / \mathrm{nsmb} .1558$

Dumdie, J. N., Cho, K., Ramaiah, M., Skarbrevik, D., Mora-Castilla, S., Stumpo, D. J., et al. (2018). Chromatin modification and global transcriptional silencing in the oocyte mediated by the mRNA decay activator ZFP36L2. Dev. Cell 44, 392-402.e397. doi: 10.1016/j.devcel.2018.01.006

Eversole, A., and Maizels, N. (2000). In vitro properties of the conserved mammalian protein hnRNP D suggest a role in telomere maintenance. Mol. Cell. Biol. 20, 5425-5432. doi: 10.1128/MCB.20.15.5425-5432.2000

Fabian, M. R., Frank, F., Rouya, C., Siddiqui, N., Lai, W. S., Karetnikov, A., et al. (2013). Structural basis for the recruitment of the human CCR4-NOT deadenylase complex by tristetraprolin. Nat. Struct. Mol. Biol. 20, 735-739. doi: $10.1038 / \mathrm{nsmb} .2572$

Fallini, C., Zhang, H., Su, Y., Silani, V., Singer, R. H., Rossoll, W., et al. (2011). The survival of motor neuron (SMN) protein interacts with the mRNA-binding protein $\mathrm{HuD}$ and regulates localization of poly(A) mRNA in primary motor neuron axons. J. Neurosci. 31, 3914-3925. doi: 10.1523/ JNEUROSCI.3631-10.2011

Fallmann, J., Sedlyarov, V., Tanzer, A., Kovarik, P., and Hofacker, I. L. (2016). AREsite2: an enhanced database for the comprehensive investigation of AU/ GU/U-rich elements. Nucleic Acids Res. 44, D90-D95. doi: 10.1093/nar/ gkv1238
Fan, X. C., and Steitz, J. A. (1998a). HNS, a nuclear-cytoplasmic shuttling sequence in HuR. Proc. Natl. Acad. Sci. USA 95, 15293-15298.

Fan, X. C., and Steitz, J. A. (1998b). Overexpression of HuR, a nuclear-cytoplasmic shuttling protein, increases the in vivo stability of ARE-containing mRNAs. EMBO J. 17, 3448-3460.

Fellows, A., Deng, B., Mierke, D. F., Robey, R. B., and Nichols, R. C. (2013). Peptides modeled on the RGG domain of AUF1/hnRNP-D regulate 3' UTRdependent gene expression. Int. Immunopharmacol. 17, 132-141. doi: 10.1016/j. intimp.2013.05.014

Fragkouli, A., Koukouraki, P., Vlachos, I. S., Paraskevopoulou, M. D., Hatzigeorgiou, A. G., and Doxakis, E. (2017). Neuronal ELAVL proteins utilize AUF-1 as a co-partner to induce neuron-specific alternative splicing of APP. Sci. Rep. 7:44507. doi: $10.1038 /$ srep44507

Friedrich, S., Schmidt, T., Geissler, R., Lilie, H., Chabierski, S., Ulbert, S., et al. (2014). AUF1 p45 promotes West Nile virus replication by an RNA chaperone activity that supports cyclization of the viral genome. J. Virol. 88, 11586-11599. doi: 10.1128/JVI.01283-14

Friedrich, S., Schmidt, T., Schierhorn, A., Lilie, H., Szczepankiewicz, G., Bergs, S., et al. (2016). Arginine methylation enhances the RNA chaperone activity of the West Nile virus host factor AUF1 p45. RNA 22, 1574-1591. doi: 10.1261/rna.055269.115

Fu, R., Olsen, M. T., Webb, K., Bennett, E. J., and Lykke-Andersen, J. (2016). Recruitment of the 4EHP-GYF2 cap-binding complex to tetraproline motifs of tristetraprolin promotes repression and degradation of mRNAs with AU-rich elements. RNA 22, 373-382. doi: 10.1261/rna.054833.115

Fujiwara, T., Fukao, A., Sasano, Y., Matsuzaki, H., Kikkawa, U., Imataka, H., et al. (2012). Functional and direct interaction between the RNA binding protein HuD and active Akt1. Nucleic Acids Res. 40, 1944-1953. doi: 10.1093/ nar/gkr979

Fukao, A., Mishima, Y., Takizawa, N., Oka, S., Imataka, H., Pelletier, J., et al. (2014). MicroRNAs trigger dissociation of eIF4AI and eIF4AII from target mRNAs in humans. Mol. Cell 56, 79-89. doi: 10.1016/j. molcel.2014.09.005

Fukao, A., Sasano, Y., Imataka, H., Inoue, K., Sakamoto, H., Sonenberg, N., et al. (2009). The ELAV protein HuD stimulates cap-dependent translation in a Poly(A)- and eIF4A-dependent manner. Mol. Cell 36, 1007-1017. doi: 10.1016/j.molcel.2009.11.013

Galloway, A., Saveliev, A., Lukasiak, S., Hodson, D. J., Bolland, D., Balmanno, K., et al. (2016). RNA-binding proteins ZFP36L1 and ZFP36L2 promote cell quiescence. Science 352, 453-459. doi: 10.1126/science.aad5978

Gama-Carvalho, M., and Carmo-Fonseca, M. (2001). The rules and roles of nucleocytoplasmic shuttling proteins. FEBS Lett. 498, 157-163. doi: 10.1016/ S0014-5793(01)02487-5

Garcia-Maurino, S. M., Rivero-Rodriguez, F., Velazquez-Cruz, A., HernandezVellisca, M., Diaz-Quintana, A., De la Rosa, M. A., et al. (2017). RNA binding protein regulation and cross-talk in the control of AU-rich mRNA fate. Front. Mol. Biosci. 4:71. doi: 10.3389/fmolb.2017.00071

Garcin, E. D. (2018). GAPDH as a model non-canonical AU-rich RNA binding protein. Semin. Cell Dev. Biol. 86, 162-173. doi: 10.1016/j.semcdb.2018.03.013

Garneau, N. L., Wilusz, J., and Wilusz, C. J. (2007). The highways and byways of mRNA decay. Nat. Rev. Mol. Cell Biol. 8, 113-126. doi: 10.1038/ nrm2104

Gherzi, R., Lee, K. Y., Briata, P., Wegmuller, D., Moroni, C., Karin, M., et al. (2004). A KH domain RNA binding protein, KSRP, promotes ARE-directed mRNA turnover by recruiting the degradation machinery. Mol. Cell 14, 571-583. doi: 10.1016/j.molcel.2004.05.002

Giovarelli, M., Bucci, G., Ramos, A., Bordo, D., Wilusz, C. J., Chen, C. Y., et al. (2014). H19 long noncoding RNA controls the mRNA decay promoting function of KSRP. Proc. Natl. Acad. Sci. USA 111, E5023-E5028. doi: 10.1073/ pnas. 1415098111

Gouble, A., Grazide, S., Meggetto, F., Mercier, P., Delsol, G., and Morello, D. (2002). A new player in oncogenesis: AUF1/hnRNPD overexpression leads to tumorigenesis in transgenic mice. Cancer Res. 62, 1489-1495.

Hall, T. M. (2005). Multiple modes of RNA recognition by zinc finger proteins. Curr. Opin. Struct. Biol. 15, 367-373. doi: 10.1016/j.sbi.2005.04.004

Hentze, M. W., Caughman, S. W., Rouault, T. A., Barriocanal, J. G., Dancis, A., Harford, J. B., et al. (1987). Identification of the iron-responsive element for the translational regulation of human ferritin mRNA. Science 238, 1570-1573. doi: $10.1126 /$ science. 3685996 
Hodson, D. J., Janas, M. L., Galloway, A., Bell, S. E., Andrews, S., Li, C. M., et al. (2010). Deletion of the RNA-binding proteins ZFP36L1 and ZFP36L2 leads to perturbed thymic development and T lymphoblastic leukemia. Nat. Immunol. 11, 717-724. doi: 10.1038/ni.1901

Hubers, L., Valderrama-Carvajal, H., Laframboise, J., Timbers, J., Sanchez, G., and Cote, J. (2011). HuD interacts with survival motor neuron protein and can rescue spinal muscular atrophy-like neuronal defects. Hum. Mol. Genet. 20, 553-579. doi: 10.1093/hmg/ddq500

Ikeda, Y., Yamaji, R., Irie, K., Kioka, N., and Murakami, A. (2012). Glyceraldehyde-3-phosphate dehydrogenase regulates cyclooxygenase-2 expression by targeting mRNA stability. Arch. Biochem. Biophys. 528, 141-147. doi: 10.1016/j.abb.2012.09.004

Kang, M. J., Abdelmohsen, K., Hutchison, E. R., Mitchell, S. J., Grammatikakis, I., Guo, R., et al. (2014). HuD regulates coding and noncoding RNA to induce APP-->Abeta processing. Cell Rep. 7, 1401-1409. doi: 10.1016/j. celrep.2014.04.050

Kasashima, K., Terashima, K., Yamamoto, K., Sakashita, E., and Sakamoto, H. (1999). Cytoplasmic localization is required for the mammalian ELAV-like protein $\mathrm{HuD}$ to induce neuronal differentiation. Genes Cells 4, 667-683. doi: $10.1046 /$ j.1365-2443.1999.00292.x

Katsanou, V., Papadaki, O., Milatos, S., Blackshear, P. J., Anderson, P., Kollias, G., et al. (2005). HuR as a negative posttranscriptional modulator in inflammation. Mol. Cell 19, 777-789. doi: 10.1016/j.molcel.2005.08.007

Khabar, K. S. (2017). Hallmarks of cancer and AU-rich elements. Wiley Interdiscip. Rev. RNA 8:e1368. doi: 10.1002/wrna.1368

Kiledjian, M., DeMaria, C. T., Brewer, G., and Novick, K. (1997). Identification of AUF1 (heterogeneous nuclear ribonucleoprotein D) as a component of the alpha-globin mRNA stability complex. Mol. Cell. Biol. 17, 4870-4876. doi: 10.1128/MCB.17.8.4870

Kraushar, M. L., Thompson, K., Wijeratne, H. R., Viljetic, B., Sakers, K., Marson, J. W., et al. (2014). Temporally defined neocortical translation and polysome assembly are determined by the RNA-binding protein $\mathrm{Hu}$ antigen R. Proc. Natl. Acad. Sci. USA 111, E3815-E3824. doi: 10.1073/pnas.1408305111

Kume, T. (2009). Novel insights into the differential functions of Notch ligands in vascular formation. J. Angiogenes. Res. 1:8. doi: 10.1186/2040-2384-1-8

Lai, W. S., and Blackshear, P. J. (2001). Interactions of $\mathrm{CCCH}$ zinc finger proteins with mRNA: tristetraprolin-mediated AU-rich element-dependent mRNA degradation can occur in the absence of a poly(A) tail. J. Biol. Chem. 276, 23144-23154. doi: 10.1074/jbc.M100680200

Lai, W. S., Carballo, E., Strum, J. R., Kennington, E. A., Phillips, R. S., and Blackshear, P. J. (1999). Evidence that tristetraprolin binds to AU-rich elements and promotes the deadenylation and destabilization of tumor necrosis factor alpha mRNA. Mol. Cell. Biol. 19, 4311-4323. doi: 10.1128/MCB.19.6.4311

Lan, Y., Xiao, X., He, Z., Luo, Y., Wu, C., Li, L., et al. (2018). Long noncoding RNA OCC-1 suppresses cell growth through destabilizing HuR protein in colorectal cancer. Nucleic Acids Res. 46, 5809-5821. doi: 10.1093/nar/gky214

Laroia, G., Cuesta, R., Brewer, G., and Schneider, R. J. (1999). Control of mRNA decay by heat shock-ubiquitin-proteasome pathway. Science 284, 499-502. doi: 10.1126/science.284.5413.499

Li, Y. R., King, O. D., Shorter, J., and Gitler, A. D. (2013). Stress granules as crucibles of ALS pathogenesis. J. Cell Biol. 201, 361-372. doi: 10.1083/ jcb.201302044

Lim, C. S., and Alkon, D. L. (2012). Protein kinase C stimulates HuD-mediated mRNA stability and protein expression of neurotrophic factors and enhances dendritic maturation of hippocampal neurons in culture. Hippocampus 22, 2303-2319. doi: 10.1002/hipo.22048

Lin, J. Y., Li, M. L., and Shih, S. R. (2009). Far upstream element binding protein 2 interacts with enterovirus 71 internal ribosomal entry site and negatively regulates viral translation. Nucleic Acids Res. 37, 47-59. doi: 10.1093/nar/gkn901

Loflin, P., Chen, C. Y., and Shyu, A. B. (1999). Unraveling a cytoplasmic role for hnRNP D in the in vivo mRNA destabilization directed by the AU-rich element. Genes Dev. 13, 1884-1897. doi: 10.1101/gad.13.14.1884

Lu, J. Y., Bergman, N., Sadri, N., and Schneider, R. J. (2006a). Assembly of AUF1 with eIF4G-poly(A) binding protein complex suggests a translation function in AU-rich mRNA decay. RNA 12, 883-893. doi: 10.1261/rna.2308106

Lu, J. Y., Sadri, N., and Schneider, R. J. (2006b). Endotoxic shock in AUF1 knockout mice mediated by failure to degrade proinflammatory cytokine mRNAs. Genes Dev. 20, 3174-3184. doi: 10.1101/gad.1467606
Lykke-Andersen, J., and Wagner, E. (2005). Recruitment and activation of mRNA decay enzymes by two ARE-mediated decay activation domains in the proteins TTP and BRF-1. Genes Dev. 19, 351-361. doi: 10.1101/gad.1282305

Ma, W. J., Chung, S., and Furneaux, H. (1997). The Elav-like proteins bind to AU-rich elements and to the poly(A) tail of mRNA. Nucleic Acids Res. 25, 3564-3569. doi: 10.1093/nar/25.18.3564

Mackenzie, I. R., Nicholson, A. M., Sarkar, M., Messing, J., Purice, M. D., Pottier, C., et al. (2017). TIA1 mutations in amyotrophic lateral sclerosis and frontotemporal dementia promote phase separation and alter stress granule dynamics. Neuron 95, 808-816.e809. doi: 10.1016/j. neuron.2017.07.025

Majumder, P., Chen, Y. T., Bose, J. K., Wu, C. C., Cheng, W. C., Cheng, S. J., et al. (2012). TDP-43 regulates the mammalian spinogenesis through translational repression of Rac1. Acta Neuropathol. 124, 231-245. doi: 10.1007/ s00401-012-1006-4

Majumder, P., Chu, J. F., Chatterjee, B., Swamy, K. B., and Shen, C. J. (2016). Co-regulation of mRNA translation by TDP-43 and fragile X syndrome protein FMRP. Acta Neuropathol. 132, 721-738. doi: 10.1007/ s00401-016-1603-8

Mansfield, K. D., and Keene, J. D. (2012). Neuron-specific ELAV/Hu proteins suppress HuR mRNA during neuronal differentiation by alternative polyadenylation. Nucleic Acids Res. 40, 2734-2746. doi: 10.1093/nar/gkr1114

Marchese, F. P., Aubareda, A., Tudor, C., Saklatvala, J., Clark, A. R., and Dean, J. L. (2010). MAPKAP kinase 2 blocks tristetraprolin-directed mRNA decay by inhibiting CAF1 deadenylase recruitment. J. Biol. Chem. 285, 27590-27600. doi: 10.1074/jbc.M110.136473

Matsui, T., Ingelsson, M., Fukumoto, H., Ramasamy, K., Kowa, H., Frosch, M. P., et al. (2007). Expression of APP pathway mRNAs and proteins in Alzheimer's disease. Brain Res. 1161, 116-123. doi: 10.1016/j.brainres.2007.05.050

Min, H., Turck, C. W., Nikolic, J. M., and Black, D. L. (1997). A new regulatory protein, KSRP, mediates exon inclusion through an intronic splicing enhancer. Genes Dev. 11, 1023-1036. doi: 10.1101/gad.11.8.1023

Mobarak, C. D., Anderson, K. D., Morin, M., Beckel-Mitchener, A., Rogers, S. L., Furneaux, H., et al. (2000). The RNA-binding protein HuD is required for GAP-43 mRNA stability, GAP-43 gene expression, and PKCdependent neurite outgrowth in PC12 cells. Mol. Biol. Cell 11, 3191-3203. doi: $10.1091 / \mathrm{mbc} \cdot 11.9 .3191$

Moir, R. D., Lynch, T., Bush, A. I., Whyte, S., Henry, A., Portbury, S., et al. (1998). Relative increase in Alzheimer's disease of soluble forms of cerebral Abeta amyloid protein precursor containing the Kunitz protease inhibitory domain. J. Biol. Chem. 273, 5013-5019. doi: 10.1074/jbc.273.9.5013

Moore, M. J. (2005). From birth to death: the complex lives of eukaryotic mRNAs. Science 309, 1514-1518. doi: 10.1126/science.1111443

Morita, M., Ler, L. W., Fabian, M. R., Siddiqui, N., Mullin, M., Henderson, V. C., et al. (2012). A novel 4EHP-GIGYF2 translational repressor complex is essential for mammalian development. Mol. Cell. Biol. 32, 3585-3593. doi: 10.1128/MCB.00455-12

Mullner, E. W., and Kuhn, L. C. (1988). A stem-loop in the $3^{\prime}$ untranslated region mediates iron-dependent regulation of transferrin receptor mRNA stability in the cytoplasm. Cell 53, 815-825. doi: 10.1016/0092-8674(88)90098-0

Murata, T., Yoshino, Y., Morita, N., and Kaneda, N. (2002). Identification of nuclear import and export signals within the structure of the zinc finger protein TIS11. Biochem. Biophys. Res. Commun. 293, 1242-1247. doi: 10.1016/ S0006-291X(02)00363-7

Nagy, E., and Rigby, W. F. (1995). Glyceraldehyde-3-phosphate dehydrogenase selectively binds AU-rich RNA in the NAD(+)-binding region (Rossmann fold). J. Biol. Chem. 270, 2755-2763. doi: 10.1074/jbc.270.6.2755

Neelagandan, N., Gonnella, G., Dang, S., Janiesch, P. C., Miller, K. K., Kuchler, K., et al. (2019). TDP-43 enhances translation of specific mRNAs linked to neurodegenerative disease. Nucleic Acids Res. 47, 341-361. doi: 10.1093/ nar/gky972

Nicastro, G., Taylor, I. A., and Ramos, A. (2015). KH-RNA interactions: back in the groove. Curr. Opin. Struct. Biol. 30, 63-70. doi: 10.1016/j.sbi.2015.01.002

Okano, H. J., and Darnell, R. B. (1997). A hierarchy of Hu RNA binding proteins in developing and adult neurons. J. Neurosci. 17, 3024-3037. doi: 10.1523/JNEUROSCI.17-09-03024.1997

Phillips, R. S., Ramos, S. B., and Blackshear, P. J. (2002). Members of the tristetraprolin family of tandem $\mathrm{CCCH}$ zinc finger proteins exhibit CRM1- 
dependent nucleocytoplasmic shuttling. J. Biol. Chem. 277, 11606-11613. doi: $10.1074 /$ jbc.M111457200

Pibouin, L., Villaudy, J., Ferbus, D., Muleris, M., Prosperi, M. T., Remvikos, Y., et al. (2002). Cloning of the mRNA of overexpression in colon carcinoma-1: a sequence overexpressed in a subset of colon carcinomas. Cancer Genet. Cytogenet. 133, 55-60. doi: 10.1016/S0165-4608(01)00634-3

Pioli, P. A., Hamilton, B. J., Connolly, J. E., Brewer, G., and Rigby, W. F. (2002). Lactate dehydrogenase is an AU-rich element-binding protein that directly interacts with AUF1. J. Biol. Chem. 277, 35738-35745. doi: 10.1074/ jbc.M204002200

Pique, M., Lopez, J. M., Foissac, S., Guigo, R., and Mendez, R. (2008). A combinatorial code for CPE-mediated translational control. Cell 132, 434-448. doi: 10.1016/j.cell.2007.12.038

Rajyaguru, P., and Parker, R. (2012). RGG motif proteins: modulators of mRNA functional states. Cell Cycle 11, 2594-2599. doi: 10.4161/cc.20716

Ramos, S. B. (2012). Characterization of DeltaN-Zfp 3612 mutant associated with arrest of early embryonic development and female infertility. J. Biol. Chem. 287, 13116-13127. doi: 10.1074/jbc.M111.330837

Ramos, S. B., Stumpo, D. J., Kennington, E. A., Phillips, R. S., Bock, C. B., Ribeiro-Neto, F., et al. (2004). The CCCH tandem zinc-finger protein Zfp36l2 is crucial for female fertility and early embryonic development. Development 131, 4883-4893. doi: 10.1242/dev.01336

Rataj, F., Planel, S., Desroches-Castan, A., Le Douce, J., Lamribet, K., Denis, J., et al. (2016). The cAMP pathway regulates mRNA decay through phosphorylation of the RNA-binding protein TIS11b/BRF1. Mol. Biol. Cell 27, 3841-3854. doi: 10.1091/mbc.e16-06-0379

Rodriguez-Pascual, F., Redondo-Horcajo, M., Magan-Marchal, N., Lagares, D., Martinez-Ruiz, A., Kleinert, H., et al. (2008). Glyceraldehyde-3-phosphate dehydrogenase regulates endothelin-1 expression by a novel, redox-sensitive mechanism involving mRNA stability. Mol. Cell. Biol. 28, 7139-7155. doi: 10.1128/MCB.01145-08

Rozen, F., Edery, I., Meerovitch, K., Dever, T. E., Merrick, W. C., and Sonenberg, N. (1990). Bidirectional RNA helicase activity of eucaryotic translation initiation factors 4A and 4F. Mol. Cell. Biol. 10, 1134-1144. doi: 10.1128/MCB.10.3.1134

Ruggiero, T., Trabucchi, M., De Santa, F., Zupo, S., Harfe, B. D., McManus, M. T., et al. (2009). LPS induces KH-type splicing regulatory protein-dependent processing of microRNA-155 precursors in macrophages. FASEB J. 23, 2898-2908. doi: 10.1096/f. $.09-131342$

Sanchez, G., Dury, A. Y., Murray, L. M., Biondi, O., Tadesse, H., El Fatimy, R., et al. (2013). A novel function for the survival motoneuron protein as a translational regulator. Hum. Mol. Genet. 22, 668-684. doi: 10.1093/hmg/dds474

Sanduja, S., Blanco, F. F., and Dixon, D. A. (2011). The roles of TTP and BRF proteins in regulated mRNA decay. Wiley Interdiscip. Rev. RNA 2, 42-57. doi: $10.1002 /$ wrna.28

Sarkar, B., Lu, J. Y., and Schneider, R. J. (2003). Nuclear import and export functions in the different isoforms of the AUF1/heterogeneous nuclear ribonucleoprotein protein family. J. Biol. Chem. 278, 20700-20707. doi: 10.1074/jbc.M301176200

Schmidlin, M., Lu, M., Leuenberger, S. A., Stoecklin, G., Mallaun, M., Gross, B., et al. (2004). The ARE-dependent mRNA-destabilizing activity of BRF1 is regulated by protein kinase B. EMBO J. 23, 4760-4769. doi: 10.1038/sj. emboj.7600477

Shen, Z. J., and Malter, J. S. (2015). Regulation of AU-rich element RNA binding proteins by phosphorylation and the prolyl isomerase Pin1. Biomolecules 5, 412-434. doi: 10.3390/biom5020412

Sinsimer, K. S., Gratacos, F. M., Knapinska, A. M., Lu, J., Krause, C. D., Wierzbowski, A. V., et al. (2008). Chaperone Hsp27, a novel subunit of
AUF1 protein complexes, functions in AU-rich element-mediated mRNA decay. Mol. Cell. Biol. 28, 5223-5237. doi: 10.1128/MCB.00431-08

Su, Y. L., Wang, S. C., Chiang, P. Y., Lin, N. Y., Shen, Y. F., Chang, G. D., et al. (2012). Tristetraprolin inhibits poly(A)-tail synthesis in nuclear mRNA that contains $\mathrm{AU}$-rich elements by interacting with poly(A)-binding protein nuclear 1. PLoS One 7:e41313. doi: 10.1371/journal.pone.0050172

Tao, X., and Gao, G. (2015). Tristetraprolin recruits eukaryotic initiation factor 4E2 To repress translation of AU-rich element-containing mRNAs. Mol. Cell. Biol. 35, 3921-3932. doi: 10.1128/MCB.00845-15

Tchen, C. R., Brook, M., Saklatvala, J., and Clark, A. R. (2004). The stability of tristetraprolin mRNA is regulated by mitogen-activated protein kinase p38 and by tristetraprolin itself. J. Biol. Chem. 279, 32393-32400. doi: 10.1074/ jbc.M402059200

Theil, E. C. (2015). IRE mRNA riboregulators use metabolic iron (Fe2+) to control mRNA activity and iron chemistry in animals. Metallomics 7, 15-24. doi: 10.1039/c4mt00136b

Trabucchi, M., Briata, P., Garcia-Mayoral, M., Haase, A. D., Filipowicz, W., Ramos, A., et al. (2009). The RNA-binding protein KSRP promotes the biogenesis of a subset of microRNAs. Nature 459, 1010-1014. doi: 10.1038/ nature 08025

Turner, M., and Diaz-Munoz, M. D. (2018). RNA-binding proteins control gene expression and cell fate in the immune system. Nat. Immunol. 19, 120-129. doi: 10.1038/s41590-017-0028-4

Twyffels, L., Wauquier, C., Soin, R., Decaestecker, C., Gueydan, C., and Kruys, V. (2013). A masked PY-NLS in Drosophila TIS11 and its mammalian homolog tristetraprolin. PLoS One 8:e71686. doi: 10.1371/journal.pone.0071686 van Gorp, A. G., van der Vos, K. E., Brenkman, A. B., Bremer, A., van den Broek, N., Zwartkruis, F., et al. (2009). AGC kinases regulate phosphorylation and activation of eukaryotic translation initiation factor $4 \mathrm{~B}$. Oncogene 28 , 95-106. doi: 10.1038/onc.2008.367

Vogel, K. U., Bell, L. S., Galloway, A., Ahlfors, H., and Turner, M. (2016). The RNA-binding proteins Zfp3611 and Zfp3612 enforce the thymic betaselection checkpoint by limiting DNA damage response signaling and cell cycle progression. J. Immunol. 197, 2673-2685. doi: 10.4049/jimmunol.1600854

Xu, N., Chen, C. Y., and Shyu, A. B. (2001). Versatile role for hnRNP D isoforms in the differential regulation of cytoplasmic mRNA turnover. Mol. Cell. Biol. 21, 6960-6971. doi: 10.1128/MCB.21.20.6960-6971.2001

Yu, M. C. (2011). The role of protein arginine methylation in mRNP dynamics. Mol. Biol. Int. 2011:163827. doi: 10.4061/2011/163827

Zhang, K., Daigle, J. G., Cunningham, K. M., Coyne, A. N., Ruan, K., Grima, J. C., et al. (2018). Stress granule assembly disrupts nucleocytoplasmic transport. Cell 173, 958-971.e917. doi: 10.1016/j.cell.2018.03.025

Zhou, Y., Yi, X., Stoffer, J. B., Bonafe, N., Gilmore-Hebert, M., McAlpine, J., et al. (2008). The multifunctional protein glyceraldehyde-3-phosphate dehydrogenase is both regulated and controls colony-stimulating factor-1 messenger RNA stability in ovarian cancer. Mol. Cancer Res. 6, 1375-1384. doi: 10.1158/1541-7786.MCR-07-2170

Conflict of Interest Statement: The authors declare that the research was conducted in the absence of any commercial or financial relationships that could be construed as a potential conflict of interest.

Copyright (c) 2019 Otsuka, Fukao, Funakami, Duncan and Fujiwara. This is an openaccess article distributed under the terms of the Creative Commons Attribution License (CC BY). The use, distribution or reproduction in other forums is permitted, provided the original author(s) and the copyright owner(s) are credited and that the original publication in this journal is cited, in accordance with accepted academic practice. No use, distribution or reproduction is permitted which does not comply with these terms. 